\title{
Vilém Flusser'in Soyutlama Modeli ve Sinematografik İmge
}

\author{
Oğuz Çağrı Kara*
}

$\ddot{O} z e t$

Vilém Flusser, kültür tarihinin ilerleyişini somuttan soyuta doğru bir yabancılaşma süreci olarak kavrayan beş seviyeli bir model önerir: 1) Dört boyutlu bir uzay-zaman sürekliliğinin somut deneyimi, 2) kavranabilir nesneleri içeren ü̧̈ boyutlu durum, 3) geleneksel imgelerle karakterize iki boyutlu gözlem ve imgelem seviyesi, 4) doğrusal metinlerle karakterize tek boyutlu tarihsel seviye ve 5) teknik imgelerle karakterize boyutsuz hesaplama ve veri-işlem seviyesi. Teknik imgeler ve geleneksel imgeler, somut deneyimden yabancilaşmanın tamamen farkh türleridir. Teknik imgelerin 'gerçekçiliği', teknik imge üreticilerinin niyetlerine bağlı olarak yanıltıcıdır. Geleneksel imgeler, dünyanın soyutlamalarıdır; teknik imgeler ise, evreni ve bilinci somutlaştırmaktadır. Flusser'in modelinden yola çıkarsak, sinematografik imge, soyutlamanın tersine işleyen somutlama sürecinin fenomenolojik tamamlayıcısıdır: Soyutlanan dört boyut, yeniden somutlanmıştır. Bu da onu, dil ötesi bir düşünce biçimi olarak en yetkin arabuluculardan biri kılar. Deleuze'ün imge taksonomisi ve Flusser'in medya kuramı birlikte okunduğunda sinematografik imgenin dil ötesi bir düşünce biçimi olarak imkanlar daha güçlü bir temelde düşünülebilir hale gelmektedir.

Anahtar Kelimeler: Vilém Flusser, hareket imge, zaman imge, temsil krizi, soyutlama, Gilles Deleuze, Henri Bergson, sinematografik imge

ORCID ID : 0000-0002-4934-9516

E-mail : oguzcagrikara@gmail.Com

DOI: $10.31122 /$ sinefilozofi.514984

Geliş Tarihi - Recieved: 20.01.2019

Kabul Tarihi - Accepted: 02.03.2019 


\title{
Vilém Flusser's Abstraction Model and Cinematographic Image
}

\author{
Oğuz Çağrı Kara*
}

\begin{abstract}
Vilém Flusser suggested a five-step model that grasps the process of cultural history as an alienation from the concrete to the abstract: 1) Concrete experience of four-dimensional space-time continuum, 2) three-dimensional situation comprising graspable objects, 3) two-dimensional observation and imagination level characterized by traditional images 4) one-dimensional historical level characterized by linear text and 5) dimensionless calculation and computation level characterized by technical images. Technical images and traditional images arise from completely different kinds of distancing from concrete experience. The 'realism' of technical images is misleading depending on the intentions of the producers of technical images. Traditional images are abstractions of world, but technical images makes the universe and consciousness concrete. If we based on Flusser's model, since the cinematographic image make four dimensions concrete, it is the phenomenological complement of the concretisation process. This makes it one of the most competent medium as a way of thinking, beyond language. When Deleuze's image taxonomy and the media theory of Flusser are read together, the possibilities of cinematographic image as an out-of-language thinking way are becoming more conceivable.
\end{abstract}

Keywords: Vilém Flusser, the movement-image, the time-image, crisis of representation, abstraction, Gilles Deleuze, Henri Bergson, cinematographic image

ORCID ID : 0000-0002-4934-9516

E-mail : oguzcagrikara@gmail.Com

DOI: 10.31122/sinefilozofi.514984

Recieved - Geliş Tarihi: 20.01.2019

Accepted - Kabul Tarihi: 02.03.2019 


\section{Giriș}

Üretilen her nesne, kültürel bir nesnedir. Ancak, doğanın nesnesi olsa dahi, isimlendirilen her şey, dünyaya dair tasarımlarımızı meydana getiren yöntemsel, biçimsel ve içeriksel kategorilerin birbirinden ayrılamayacak derecede yoğunlaştığı dil içinde kültürel nesneye dönüşür. Doğanın nesnelerinin isimlendirilmeden önce de orada; 'dışarıda' mevcut oldukları varsayıldığı gibi, kavram meydana gelmeden önce, kavramın koşullarının kültürün doğasında oluştuğu varsayılabilir. Bu anlamda, 'zihinsel tasarımları',' nesneler arası ilişkiselliği' çağrıştıran 'kavram' ve dünyada; dışarıda olan tekil şeyleri çağrıştıran 'nesne' ayrımı; dil içi, yapay bir ayrımdır. 'Kavram', -bir soyutluk derecesi belirleyebilecek olmamızla birlikte- dilsel açıdan kavranmış olan her şeydir, dilin tüm öğeleridir. Dilsel öğeler, kültürel ağı oluşturan belli bir arabulucunun (dilsel/metinsel medyanın) öğeleridir ve değişim geçmişinden de görüleceği üzere medya, 'düşünce' için sadece bir araçtır.

Dilsel bir pratik olarak görülmediği, her türlü kültürel pratikte biçimlenebilen akışkan bir güç olarak yaklaşıldığı sürece kullanışlı bir kavram olan 'düşünce', özgür ifadesini bulacağ1 araçlara yöneldiği ölçüde medyayı değiştirmekte; değişen medya da düşünce biçimini değiştirmektedir. Yeni medya biçimlerinin başını çektiği paradigma değişimi, bu türden bir değişime işaret etmektedir. Düşüncedeki bu değiş̧imin sebebi, teknik imgeler üzerine kurulu yeni medyanın düşünceyi, eski medyanın temsili yapısından bağımsızlaştırmaya başlamış olmasidir.

'Temsil krizi' tartışmalarının esas odağının medya olmasına dair gereklilik, belli bir nedenle çok açıktır: 'Medya' (Media), 'araç, aradaki şey, aracı' anlamına gelen Latince 'medium'un çoğul halidir. Araç, bir arabulucudur: İnsan (özne) ve dünya (nesne) arasında arabuluculuk yapar. Bu, tüm kültürel ürünlerin özelliğidir. Ancak, medya, özneler arası arabuluculuğu da üstenen araçtır: Bir iletişim aracıdır. Bu da medyayı araç olmanın yanında (özne ve nesnenin arabulucusu olmanın yanında), düşünce için özneler arası bir dolaşım ortamı yapar. 'Ortam', 'medium'un diğer bir anlamıdır. Sonuç olarak, medya, hem bir araç; hem de bir ortamdır. Kültürel bir araç, içinde bulunduğu ortamla anlamlandırılabilir. Öyleyse, düşünce için hem bir araç, hem de bir ortam olma özelliğini gösteren şey, dünya görüşünün; 'ideoloji'nin kendisi olur. Bu sebeple, medyanın doğasına inmek, bize, dünyayı nasıl gördüğümüzü 'gösterecektir'. Flusser' in medya felsefesinin altında bu yaklaşım yatar.

Flusser'in medya kuramına, medya niteliklerini bilişsel dönüştürücüler olarak kavraması açısından McLuhancı bir yaklaşım denebilir. Ancak, onun kuramı birçok açıdan McLuhan'ın kuramından farklılaşır. Enönemli fark, Flusser'in, McLuhan'ın medya kuramlarına getirdiği "araç mesajdır" şeklinde mottolaşan bakış açısını belirlenimci çizgisinden ve parçalı yapısından kurtararak fenomenolojik ve diyalektik bir bağlama oturtmasıdır. Ve bu farka bağlı olarak, yeni medya biçimlerinin kültürü 'modern öncesi' biçime yakınlaştırdığına dair McLuhancı saptamaya tamamen karşıt bir yaklaşım geliştirmiştir. Flusser'in 'teknik' ve 'geleneksel' imgelere özsel bir ayrım yüklemesi, bu karşıtlı̆̆n temelini oluşturur.

İmge, antik zamanda yazının öncülü; yazının hakimiyetindeki kültürel durum boyunca ise, büyük oranda, -yazı öncesinde de varlığı kabul edilen- görsel sanatın öğesidir. Tarih öncesi durumda, imgenin iletişimsel ve sanatsal nitelikleri daha bütünsel bir medya biçiminde yoğunlaşır. Sembolikleşen imge, yazıyı meydana getirerek hakim iletişim biçimini oluşturmuş; imge ise, yazının karşılayamadığı imgesel düşünceyi taşımaya devam ederek yazıyla diyalektik içinde evrilmiştir. İmge üretim biçimlerindeki sanayi sonrası değişim, 
medyanın ve medya yoluyla dolaşıma giren dil ve sanatın -antik durumunda olduğu gibitekrar birbirlerinin çekimine girdiği ve aralarındaki çekim gücünü bilim ve bilimsel tekniğin oluşturduğu yeni bir kültürel durumu; gerçek anlamda kültürel bir devrimi meydana getirmektedir. Bu devrim, metinlere ve metinlerin soy kütüğünde bulunan temsili imgelere dayalı temsil sistemine dönüş değildir: Teknik imgeler üzerine kurulu bütünsel bir sanatın veya bütünsel bir dilin; dünyayla ilişkimizde tasarımlarımızı var ettiğimiz yeni bir medyanın ve bu medyaya bağlı yeni bir bilincin şafağıdır (Flusser, 1986: 331).

Sürekli dile getirildiği biçimiyle "imgelerle çevrili olduğumuz çağ" da üretilen imgelerin kavram dışı bir düşünme edimine duyulan -gizli- ihtiyacı karşılamak üzere var olduklarını söylemek artık mümkün gözükmektedir. Diğer açıdan, çevremizi saran imgeler, bizi ‘imgelerle düşünme' ye daha fazla itmektedir. Belli bir açıdan bakıldığında onlar, teknolojik bir gelişmenin kaçınılmaz sonuçları veya "daha az okuyup, daha fazla seyretmeye" iten pasifleştiriciler değil; sonsuz bir potansiyeli olan düşüncenin kendini gerçekleştirme yolunda gösterdiği belirtilerdir (Baker, 2011: 39-40). Teknik imgenin, teknik meselelere indirgenemeyecek, aynı zamanda -en azından bir dil sistemine gönderecek şekilde- sembolik olmayan 'düşünsel' yanı gittikçe belirginleşmektedir: Görsel antropoloji, Gilles Deleuze'ün sinema felsefesi, Ulus Baker'in belgeselcilikle sosyal bilimleri bağdaştırma girişimi olan 'duygular sosyolojisi' gibi eğilimler, 'kavram'ın yerine -diyalektik bir şekilde- geçmeye başlayan teknik imgenin sinematografik biçimine dair girişimlerdir ve sinematografik imge, teknik imgenin sadece bir yüzüdür. Bugün, teknik imgelerle karakterize yeni medyaya eski medya biçimleri lehine bir karşı çıkış, bizi, yazı karşıtı sözlü kültür gelenekçileriyle veya matbaa karşıtı el yazmacılarıyla benzer bir konuma yerleştirecektir.

Sinema, -belki de benzer tartışmalar daha önce fotoğraf için de yapıldığı için- icadından kısa bir süre sonra etkili bir sanat ve iletişim biçimi olarak kabul edilerek gelenekçi yaklaşımları kıran ilk teknik sanatlardan olmuştur. Ancak, sinema, -teknik gelişmeleri bir yana bırakacak olsak bile- zaten sonsuz bir potansiyelle doğmuştur. Sinemanın potansiyeli çoğu zaman, kamera ve film şeridiyle ne yapılabileceğini düşünebilme ölçüsüyle sınırlanmıştır: Tüm sinema tarihi boyunca kullanılacak birçok teknik için Georges Méliès'in sihirbaz kurnazlığını sinematografa uygulaması yeterli olmuş; -belki de- refleksif bir davranış, kameranın hareket ettirilmesi fikrini 'akla yatkın' kılmıştır (The Great Train Robbery, Edwin S. Porter, 1903). Sinema, icat edildikten sonra sürekli keşfedilen bir sanattır ve bu keşif, -onun potansiyeli gereği- daha önce hiçbir sanatta olmadığı kadar içsel bir keşifle eşzamanlıdır.

Vilém Flusser, -doğrudan sinematografik imgeye değinmese de- bir teknik imge sanatı olan sinemanın bu potansiyelini daha yakından görmek adına etkili bir kuram geliştirmiştir. Diğer yandan Gilles Deleuze'ün imge taksonomisi, sinemada gerçekleşen bu düşünsel potansiyeli irdeler. İnceledikleri öğelerin doğası gereği göstergebilimsel çözümlemeler yerine, doğrudan imgesel bir öze inme amacında Deleuze ile aynı zeminde buluşan Flusser' in kuramin Deleuze ve Henri Bergson'la birlikte okumak, sinematografik imgeye dair daha derin bir kavrayışı mümkün kılacak; sinematografik imgenin yükselen yeni kültürde dünyayı anlamlandırışımızda nasıl bir konuma yerleştiği daha net görülecektir.

\section{Flusserci Bakış}

Son dönemlerinde medya felsefesine yoğunlaşmış olan Vilém Flusser'in Türkiye'deki az bilinirliği, makalede onun bakış açısı üzerine bir tanıtım için gerekli motivasyonu sağlayan sebeplerden biridir. Diğer bir sebep ise, Flusser' in teknik imgelere yönelme niyetinin bu bakış 
açısından doğmuş olmasıdır.

Çek doğumlu olan Vilém Flusser (1920 - 1991), eserlerini büyük oranda Portekizce ve Almanca kaleme alsa da, İngilizce ve Fransızca çalışmaları da bulunmaktadır. Önemli eserlerinin henüz İngilizceye dahi yakın zamanlarda çevrilmiş olması, Türkiye'de yeterince tanınmamasının esas nedenlerinden biridir. Flusser'in yazıları, neredeyse tek bir bakış açısı üzerinden birbirini tamamlar. 1963 yılında yaptığı Düşünce ve Düşünüm adlı konuşması çağdaş felsefelerin ortak hedefi olan Kartezyen düalizme yaklaşımını gösterdiği için bu bakış açısını kavramada iyi bir başlangıç olacaktır.

Flusser, aralarındaki ilişki Tanrı'nın yardımı (concursus Dei) ile kurulan Kartezyen 'düşünen şey' (the thinking thing) ve 'uzamlı şey' (the extended thing) ayrımının, Batı medeniyetinin Hıristiyanlık temelli düşünsel köklerine dek izinin sürer. Bu ayrım, aynı zamanda, Batılı bilimin başarısını borçlu olduğu şeydir: Düşünen şeyin (özne) nesneleri anlamak üzere nesneleri kuşatışı bilimsel yöntemi; düşünen şeyin nesneleri değiştirmek üzere nesnelere tutunuşu ise teknolojik yöntemi oluşturur. Ancak, bu iki yöntemin başarısı, aynı zamanda Batı medeniyetinin sonunun da başlangıcıdır. Özne ve nesnenin, artan oranda birbirlerinin alanını işgal etmesiyle birlikte sınırlar görünmez olmaya başlamıştır (Flusser, 2005: 7):

"Batı düşüncesinin maddesel dünyaya karşı ilerleyişindeki epistemolojik ve etik kuşatmalar, Batılı düşüncenin meydana getirdiği Kartezyen görüşten kaynaklı bir şeyin yoksunluğunu (belki de "concursus Dei"nin) ilerlemeli olarak ortaya koymaktadır. Örneğin: Modern fizik, ilerleyen bir şekilde, birçok yönden maddenin temelinin düşünce olduğunu göstermektedir. Çünkü pozitronlar, nötrinolar gibi madde unsurlar, her şeyden daha çok, düşüncenin sembolleri gibidir ve bu sebeple, temel işlem olan 'nesne'den 'özne'nin ayrilışı mümkün olmamaktadır."

Flusser'e göre, bu krizi anlamanın yolu, Descartes tarafından temellendirilip Modern Çă̆'da ise Batı tarafından ilerlemeci bir şekilde gerçekleştirilen 'düşünce' kavramını takip etmekten geçer. Kartezyen 'madde ve düşünce, beden ve ruh, şüpheli ve şüphesiz' ayrımları, halihazırda Batı medeniyetinin temel efsanelerinden birinde mevcuttur: Cennetten kovuluş. Cennet, tüm bu ayrımların olmadığı yerdir. Cennetten kovulma efsanesi, -basitçe- düşünmenin değil, belli bir düşünce biçiminin ortaya çıkışını; Batı düşüncesinin ortaya çıkışını anlatır. Efsanedeki yasak meyve; iyilik ve kötülük, şüphe ve bölünmenin meyvesidir. Cennet, şüphesizlik ve bölünmezlik durumudur. İnsanın sürüldügü yer ise, bölünmüş bir kesinliğin düzenidir (kozmos). Şüphe duymak, cennetten kovulmaktır. Flusser, 'şüphe' anlamındaki 'doubt' ve 'çift' anlamındaki 'duo' kelimelerinin etimolojik yakınlığı üzerinden bu görüşü destekler (Flusser, 2005: 9).

'Düşünüm' (reflection), bir ayrımın sonucu olan 'düşünce'nin henüz başlamadığı bütünlüğe (cennete) geri dönmeye yönelik bir davranıştır. Düşünüm, nesneleri yutmak üzere nesnelere doğru genişleyen ve bunu gerçekleştirme yöntemi bilim ve teknoloji olan düşüncenin hareket ettiği yönün tam tersine ilerler. Düşünüm, düşüncenin kendini yutmak ve değiştirmek üzere kendine doğru ilerlemesidir. Bu durumda düşünce, kendini parçalara ayırmak ve kontrol etmek üzere ilerler. Düşünüm, felsefedir. Öyleyse felsefe, bilim ve teknolojinin tam tersidir. Flusser'in buradan çıkardığı sonuç, 'şüphe' ve 'düşünme'nin aynı şey olduğudur. Kartezyen düşünen şeyin şüphesizliği, düşünen şeyin 'düşünen şey' olmasından kaynaklanır (Flusser, 2005: 9-10): 
"Şüphe, düşünce anlamma gelir, bu nedenle saçma bir süreçtir. $O$, şüpheye son vermek için şüphe duyar ve ilerledikçe, şüpheli olanı (nesnelerini) şüphesize dönüştürür. Şüphe, bu yüzden iki kat saçmalıktır: Saçmadır, çünkü düşüncenin amacı, kendi kendini yok etmektir; saçmadır, çünkü düşünce, her şeyden şüphe duyarak bu saçma hedefe ulaşmaya çalışır. Düşüncenin saçmalığı; susuzluğu, denizin suyuyla bastırmaya çalışmakla karşılaştırılabilir. Saçmadır, çünkü deniz bitmek tükenmez; saçmadır, çünkü ne kadar içilirse içilsin susuz kalınır. Düşünce ilerledikçe belirginleşen şey, onun çifte saçmalı̆̆ıdır, Cennetten kovuluşumuzdur."

Böylece "Şüpheli olan nedir?" sorusu, sözde bir soru haline gelir. Çünkü bu soruya verilebilecek herhangi bir cevap soruyu cevaplamaz: Soruyu geçersiz kılar. Bu soruya verilecek herhangi bir cevap, şüpheli bir tanım olmalıdır. Ancak, tanımlanmış bir şüpheli, artık şüpheli değildir. Şüphesizliğe ulaşmak, bütünlüğe (cennete) ulaşmamız anlamina gelecektir. Aslında, 'şüpheli', tanımlanacak bir şey değil, sadece üzerine 'düşünülecek' bir şeydir. Bu durumda 'şüpheli' bir 'şey' bile olamaz: Düşüncenin ufku; düşüncenin genişlediği yer olabilir. Düşünce sonsuza dek genişler, şüphe ise onu sınırlayan bir durum olarak belirir. Düşünce, şüpheli olana 'karşıt' değildir: Düşünce, şüphe ederek şüpheli olanı bir 'şey' kılar. Sonuç olarak düşünce, bir gerçekleştirme sürecidir (Flusser, 2005: 9-10).

Flusser, "düşünce hangi düzende genişler" sorusuna 1963 yılı itibariyle şu cevabı verir: "Düşünce, dil kurallarına uygun olarak oluşturulan ve birbirini aynı kurallara göre takip eden cümle zincirlerinde genişler." Bir ağ metaforu verir: Düşünce, iplerin dilin kurallarl; düğümlerin şüphenin eklemlenmeleri (artikülasyonları); gözeneklerin sözle anlatılamayan, araya giren sezgiler olduğu genişleyen bir ağdır. Bu ağın kimi kısımları yoğun (fizik gibi), kimi kısımları kararsız ve gevşektir. Örneğin, matematik dilinin kuralları neredeyse tamamen 'anlatılamaz' olanı kapsamakta ve böylece geriye neredeyse 'düşünülecek' bir şey bırakmamaktadır: Şüpheli olan dile dönüşmüştür. Flusser, umudu, dil ağının 'kararsız' ve 'gevşek' yerlerinde görür. 'Sözle anlatılamayanlar', kelimelerin arasındaki açıklıklarda gizlenmiştir. Yeni kelimeler ve düşünceler, bu açıklıklar sayesinde sürekli ortaya çıkmaktadır (Flusser, 2005: 10-11).

Flusser'in Cennet metaforu, ilk başta Lacancı bir bütünlük gibi görülebilir: İki bakış açısı da dil yoluyla çözülen ve yine de dil yoluyla peşine düşülen bir gerçeklik idealine işaret eder. Ancak, Flusser'in Cennet'i, Lacan'ın imkansız psikolojik bütünlüğüne karşın, paylaşılan bir şey; bir ütopya olma özelliğine sahiptir, ikinci dereceden bir bütünlüktür ve imkansız değildir: Batı Medeniyeti bu 'ütopya' için kusursuz bir şekilde işe yarayan araçlara sahiptir: Bilim ve teknoloji. Bu ütopyanın gerçekleştiği noktada düşünce, matematiksel ve biçimsel olarak mantıksal yapılara indirgenebilecek ve böylece sıfıra da indirgenebilecektir. Flusser'in, hafife alındığını düşündüğü bu 'ikinci dereceden cennet' tehlikesine karşı çözüm önerisi, bilimde olduğu kadar kesin ve yoğun olmayan diyalog seviyelerini dilde açmaktır. Sanat ve din, bilimsel unsurlar tarafından istila edilene kadar böyle seviyelerdir, ancak artık 'ilerleme'nin yönünü saptıramayacak kadar yıpranmışlardır. Sadece, yöntemsel düşünüm bunu yapabilir, çünkü yalnızca yöntemsel düşünüm bir bilim eleştirisidir. 'Şüpheden şüphe eden' felsefe, dini söylemin üzerinden düşünüme gitmiş ve yeni bir söylem olan bilim için kapı aralamıştır. Şimdi ise, bilimsel söylemin üzerinden düşünüme gitmektedir ve böylece, -her zaman olduğu gibi- yeni olasılıkları mümkün kılacaktır (Fluser, 2005: 10-12).

Flusser'in henüz bir medya kuramı geliştirmeden önce yaptığı bu konuşmada vurguladığı, ancak ileride dağılmaya mahkum olan şey, düşünceye yüklediği dilselliktir. Flusser' in kilit düşüncelerinden olan 'her medya için belirli bir mantık' fikrinin tohum halinde 
bulunduğu, dilin sadece bir gerçeklik haritası (Wittgenstein) olarak düşünülmediği; kendisi ile gerçeklik arasında geribildirim oluşturan bir şey olarak düşünüldüğü Dil ve Gerçeklik (Língua e realidade) adlı kitabı da yine 1963 yılında yayınlanmıştır (Hanke, 2004). Erken dönemlerinde düşünceye yüklediği dilsellik ve bilim ve teknolojiye karşı bu dilsellik üzerinden felsefi bir düşünce alanı açma niyeti onu, bilim ve teknolojiyle barışık, dilsel olmayan bir düşünce alanına yöneltmiş gözükmektedir.

Flusser'in Kartezyen düalizme yaklaşımı, mutlak bir bütünlük (cennet) inancını yıksa da, karamsar bir nihilizmle sonuçlanmaz. Gerçeklik idealini yitirme pahasına bu 'saçma' düşünme davranışında cesurca ısrar etmenin, -her zaman olduğu gibi- yeni açılımları doğuracağı inancını sürdürmektedir. Ancak, açılım bu sefer keskin bir kırılmayla birlikte gerçekleşir: Düşüncenin ileri-geri hareketi, üzerinde bulunduğu yapıyla (dil) aynı frekansa ulaşmakta ve bu rezonansal eşitlik, yapının parçalamasına sebep olmaktadır. Kökten bir dil eleştirisine yönelen modern felsefe bu durumun en net göstergesidir.

Düşünce, içinde genişleyebileceği ve kendine dönebileceği dil ötesi yeni bir alana taşmaya zorlanmaktadır. Başka bir deyişle dil, kendine dönen düşüncenin baskısıyla kendi üzerine çöker ve yeniden dağılacağı uzamı dil içinde bulamaz: Dilin sınırları, tüm düşünceyi içine çeken bir tekilliği olanaksız kılmaktadır. Bu sebeple dil, daha çok, bir süpernova gibi davranır: Düşünceyi taşıyamadığı noktada dağılır. Düşünce ise, dağılma eğilimindeki enerji gibi, yine kendisinin var ettiği taşıyıcılara doğru taşar. Daha doğrusu, düşüncenin var ettiği şeyler, bu kırılmadan itibaren düşüncenin taşıyıcısı olma niteliğine bürünür.

Düşüncenin taştığı yer, bir zamanlar tarif edilemeyenin yeriolan din ve sanatı parçalayan bilim ve teknolojiden başkası değildir. Bilim ve teknoloji, amaç olmaktan çıkmakta, dili tüketen düşünceye yeni ufuklar sağlayacak nesnel imkanları sunan bir araca dönüşmektedir. Bu zamana kadar nesneleri kavrama ve değiştirme eğilimindeki bilim ve teknoloji, dil ötesi düşünce araçları üretmeye başlamıştır. Bir anlamda bilim ve teknoloji, kendi mitolojisini oluşturmakta; 'anlatılamayan', artık, teknik imgelere dair olmaktadır. Teknik imgeler, 'satır araları' nın yeni, görünür biçimidir.

\section{Medya Kuramlarına Güçlü Bir Alternatif Olarak Flusserci Yaklaşım}

İnsanlı̆̆ın yaşamı, başka canlılara göre genetik bilgiden çok, öğrenilen bilgiyle ilgili olduğundan, bilginin aktarıldığı yapı, yaşamlarımız üzerinde belirleyici bir etki yaratır. (Flusser, 2011: 5).

Medya teknolojilerine yönelme eğilimindeki kuramlar, genellikle iki temel kültür biçimi tanımlama eğilimindedir: Sözlü ve yazılı kültür. İmgenin sözden yazıya geçişte oynadı̆̆ı rol, çoğu zaman üzerinde pek de durulması gerekmeyen sıradan bir dilbilim veya antropoloji bilgisi olarak sunulmaktadır (Kaldı ki, 'söz', sanayi sonrası aygıtlarca kaydedilme ve uzak mesafeler katedebilme imkanına ulaşmadan önce 'yayınlanabilir' değildi). Bu hatırlatma, sadece, medya diyalektiğinin eksik parçasını yerine koymak için değil; yazılı medya biçiminden ne ölçüde yabancılaştı̆̆ımızı göstermek için de önemlidir. ${ }^{1}$

Kültürel bir dönüştürücü olarak medya teknolojilerinin niteliklerine yönelen kimi kuramların teknolojik belirlenimci yaklaşımı teknolojik gelişmeleri doğal, verili fenomenlermiş gibi görerek yeni teknolojileri var eden düşünsel evrimi iskalamakta ve bu sebeple yeni teknolojilerin biçimlendirdiği kültürel yapıyı kavramada kesintili ve eksik kalmaktadır.

1 Birçok felsefede anahtar bir kavram olan 'yabancllaşma', Flusser' in felsefesinde 'hakim medya biçiminden yabancılaşma' olarak karşımıza çıkar. 
Teknik imgelerin, henüz yabancılaşmaya başladığımız metinlerin sonuçları oldukları (Flusser, 1991: 17) göz önünde bulundurulduğunda bu tutum daha anlaşılır olacaktır.

Medya teknolojilerininözgünniteliklerineyönelen yaklaşımların yüzleşmesi gereken bir diğer şey de bu yaklaşımları hakim ideolojileri meşrulaştıran, sosyolojik ve kültürel bağlamdan uzak yaklaşımlar olarak gören (Stevenson, 2008: 212) 'eleştirel yaklaşım'lardır. Eleştirel medya kuramcılarınca paylaşılan sanayi sonrası bir durum olarak imgenin araçsallaştırıldığına, sahte bir estetizm içine sokulduğuna (Jameson, 1998: 134-135) benzer görüşler birçok yönden haklı olsa da, yeni medya teknolojilerinin sanatsal ve iletişimsel olanaklarını görmezden gelebilecek ölçüde indirgemeci olabilmekte, aynı zamanda diğer birçok alanda olduğu gibi; medya üzerine çalışmalarda kısır bir döngüde tekrar eden hazır bir kültür eleştirisi modeli sunarak 'entelektüel yatıştırıcı' işlevine bürünebilmektedir. Teknik gelişmeler, kapitalist yapının ürünleri olsa dahi, "Politik, ekonomik, sosyal veya estetik olsun tüm devrimler, son tahlilde, teknolojik bir devrimdir." (Flusser, 1988) 'Eleştirel' yaklaşımlarının belirleyici kaynağı olan Marksist 'yabancılaşma' nosyonunun, 'yanlış bilinç' olarak addettiği 'ideoloji'nin karşısında kendi yöntemlerini mutlaklaştırması -her ne kadar Aydınlanma'nın radikal hümanizmini kırmış olsa da- 'insan doğası' na karşı özcü bir yaklaşımın sürdürüldüğünü göstermekte, ve bu da onu, teknoloji karşıtı (luddite) bir konuma sürüklenmeye yatkın kılmaktadır. Marksist gelenek içinden gelen Althusser, ideolojiyi özneyi özne yapan şey kılarak ortodoks söylemlere karşı halihazırda etkili bir eleştiri getirmiştir. Ancak, bu durum, yabancılaşma kavramından vazgeçmemizi gerektirmez; hatta ona daha uç bir tanım getirmemiz gerekir: Yabancılaşma, sadece, üretim-tüketim ilişkilerinden ve buna bağlı insani ilişkilerden yabancılaşma süreci değil; tüm bu kültürel durumları kapsayan varoluşsal bir süreçtir. Kültürel üretimin bize gösterdiği şey, 'yabancılaşma'nın sadece belli bir yapının sonucu değil; doğrudan doğruya insanın yazgısı olduğu; insanın yabancılaşarak 'insan' olduğudur. Yabanclaşmanın her aşamasında yeni bir bilinç doğmakta, her yeni bilinç, dünyaya uyumlanmak üzere kendi öngörülemez ürünlerini üretmektedir. Bu, öngörülemezlik, Marx'1n 'önceden tasarlanan' bir şey olarak tanımladığı üretimin (Aktaran: Fischer, 1990: 15) tasarlanmayan, semptomatik yanıdır ve -Marx'ın insan üretimiyle karşıtlık kurmak üzere örneklediği- arının içgüdüsel üretimi olan petek veya örümceğin ürettiği ağ kadar işlevseldir.

Türkiye' de medya teknolojileri üzerine tartışmalarda çoğu zaman, bir tarafında artık neredeyse doktrinleşmiş bir 'eleştirel kuram'ın; diğer tarafında ise, kapitalist üretim-tüketim biçimlerinde bu teknolojileri araçsallaştırma çabalarının bulunduğu bir kutuplaşma ve her iki kutba da hizmet edebilen göstergebilimsel yaklaşım üçgeniyle karşılaşmaktayız. 'Görsel kültür' olarak da adlandırılan yeni durumda imgeler, dili aşan göstergelerdir. Göstergebilim, tüm kültürel pratikleri irdeleme amacında olsa da, yöntemlerini teknik imgelerin tamamen yeni olan niteliklerine 'işaret' etmek üzere kullanmak yerine; onların taşıdığı 'anlamları' açılamak üzere kullanma yoluna gittiği sürece, medya yapıları için geçerli bir ölçü oluşturamayacaktır: Son tahlilde, imgelere uygulanacak bir göstergebilim, imgeleri başka bir koda; dile çevirme çabasından ibaret olacaktır. Flusser'in de belirttiği gibi, göstergebilime olan güncel ilgi, aygıtlarla etkileşimimizde parmak uçlarımızın önemli bir yer tuttuğu yeni kültürümüzün bir etkisi olarak düşünülebilir. Göstergebilim, 'işaret' ve 'anlam'ı aynı potada eritmeyi başarmıştır (Flusser, 2011: 41).

Eleştirel ve göstergebilimsel kuramlar, bir yanda kapitalizmin araçsal aklını dizginlemeye, diğer yanda dünyaya dair 'anlam'ı yeniden tesis etmeye çalışarak 'akıldışılığa' 
doğru bir gidişata direnç oluşturma işlevini yeterince yerine getirmekte; toplumsal bir süperego oluşturmaktadır. Ancak, belirli ihtiyaçları olan biyolojik arzuların aksine, her yeni durumda dönüşmekte olan toplumsal arzular için tamamen yeni bir yayılım alanı olan yeni medya teknolojilerinin daha derinden aydınlatılması gereken fenomenler oldukları ve böylesi bir aydınlatma çabasının yeni bir toplumsal bilincin inşasında belirleyici olacağı da göz önünde bulundurulmalıdır.

Bu yeni insanlık inşası, gerçekten 'akıldışı' olabilir. Flusser' in de önerdiği gibi, artık, dünyaya dair tasarımlarımızda gerçek-yanlış, gerçek-yapay gibi ayrımlar yerine; içinde her şeyin mümkün olduğu bir 'soyut-somut' skalasına başvurmamız gerekebilir (Flusser, 2011: 38). Kavramlara başvurmadan 'bilemediğimiz' tarih öncesi insanının 'büyüsel' bilincinden yabancılaştı̆̆ımız gibi 'rasyonel' bilinçten yabancılaşmayacağımızın güvencesi yoktur. Ratio, 'hesaplama becerisi' dir ve bu beceri artık, insandan çok, aygıtlara dair bir beceriyi çağrıştırmaktadır. Aygıtın 'rasyonel' karaktere ulaşması, insanın onun ötesinde bir niteliğe bürüneceğini gösterir. $\mathrm{Bu}$, insan-araç diyalektiğinin altında yatan basit prensiptir. $\mathrm{Bu}$ durumda, yeni medya, tarihsel bilgiyi yok ederek yanlış bir zamansal bilince neden olan gösteriler (Debord, 1996: 88) olarak değil; içinde bulunduğumuz tarih sonrası durumu akla yatkın hale getiren arabulucular (Flusser, 2011: 10) olarak kavranabilecektir. Baudrillard, insan doğasının ihtiyaçları yerine, değişken toplumsal ihtiyaçları getirdiğinde Flusser'in bu yorumuna yaklaşmıştır. Ancak, varmış olduğu karamsar nihilizm, dilsel karşılığı olmayan bir 'gerçeklik' karşısında duyulan hayal kırıklığının sonucu gibi gözükmektedir. Flusser, temsil sisteminin krizini kabul etmekle birlikte; temsili olanın dışında bir tahayyül geliştirme girişiminde bulunarak riskli ama umutlu bir sürece cesurca kapı aralar. Flusser için gerçekliğin reddi, ideali sürmekte olan bir gerçekliğin değil; tarihsel bilince dair 'belirli bir hakikatin' reddi olacaktır.

\section{Teknik İmge ve Geleneksel İmge}

Flusser' in Ins Universum der technischen Bilder (Teknik İmgeler Evrenine Doğru) adlı çalışmasında geliştirdiği model, Für eine Philosophie der Fotografie (Bir Fotoğraf Felsefesine Doğru) adlı çalışmasında temellerini attığ fikirlerin devamı ve gelişimi niteliğindedir (Flusser, 2011: 3). Flusser, Bir Fotoğraf Felsefesine Doğru'da, teknik imge ve geleneksel imge ayrımını, imgelerin üretim biçimleri açısından değerlendirir. İmge üretiminde evvelden beri teknik bir yönün olduğu doğrudur (Baker, 2014: 225). Ancak, 'teknik' kavramina bu derece geniş bir anlam yüklemek, düşünceyi, Flusser'in göstermeye çalıştığ1 esas noktalardan saptıracaktır: Flusser, 'alet' ile üretilen geleneksel imgenin karşısına 'aygıt' (apparatus) ile üretilen teknik imgeyi konumlandırır. Alet, nesnelere yeni biçimler vererek onları kültürel ürünler haline getirmeye yarar. Onlar, biçimsel özellikleriyle insan uzuvlarına benzemekle birlikte, insan uzuvlarının işlevselliğini arttırır. Aygıt ise, 'kendini bir şeye hazırlayan nesne'dir. İlk teknik imge, fotoğraftır. İmge üreten bir aygit olan fotoğraf makinesi, otomasyona sahiptir: Onun imge üretim süreci, kapalı bir kutunun içinde, gözden ve elle müdahaleden uzakta gerçekleşir. İnsanın kendi kültürel ürünleriyle ilişkisi de bu otomasyon sebebiyle keskin bir değişime uğrar: İnsanların aletlerle çevrili olduğu durumdan makinelerin insanlarla çevrili olduğu sanayi sonrası duruma gelinmiştir. Fotoğrafçı ve aygıt arasındaki ilişki; bütünsel, iç içe bir yapı oluşturur (Flusser, 1991): 
“Bu insanın ne sabit, ne de değişken bir öğe olduğu fakat aygıt ile işlevsel bir bütün oluşturduğu yeni türde bir ilişki biçimidir. Bundan dolayıdır ki; daha çok fotoğrafçının aygıtın bir 'işleten'i (functionnaire) olarak anilmast gerekir."

Geleneksel imgeler, içinde yaşanılan dünyadan doğrudan soyutlamayla elde edilirken; teknik imgeler, imgelerin de soyutlanmasıyla elde edilen metinleri 'kasteder'. Bu açıdan yaklaşıldığında teknik imgenin 'nesnelliği' yanıltıcıdır: Onlar, metinlerden daha soyut şeylerin somutlamalarıdır. Ontolojik açıdan, geleneksel imgeler 'görüngüleri' kastederken, teknik imgeler 'kavramları' kastederek onları yeniden kodlar. Geleneksel bir imgenin deşifresi, imgeyi üretenin zihinsel sürecine dair bir kod açımını gerektirmekteyken, teknik imge ile teknik imgenin nesnesi arasında geleneksel imgenin üreticisi gibi bir dolayım yoktur: Aygıtın içsel dolayımı vardır (Flusser, 1991: 17-19).

Örneğin, bir teknik imge olan fotoğrafın nesnellik izlenimi yanıltıcıdır çünkü fotoğraf makinesi, gözü model alır. Bu sebeple onun "bir nesnelliği olduğu gibi yüzeye aktardığı" söylenemez. Fotoğraf, gözün ilkelerine dayanarak oluşturulan bir aygitın süzdüğü ışı̆̆ın yüzeye aktarımıdır: Bir gerçekliğin değil, bir görüngüsel gerçekliğin yüzeye aktarımıdır. Örneğin, kızılötesi ve x-ray gibi görselleştirme teknolojileri, ışığın yüzeylere bıraktığı izler olması bakımından herhangi bir fotoğraf makinesinin yaptığından farklı bir şey yapmaz. Görülebilir ışık tayfı ne kadar gerçekse morötesi de o kadar gerçektir. Ancak, sadece morötesi ışık tayfını yansıtan bir fotoğraf, bizim için -çevremizdeki morötesi ş̧ınlar gibi- görünmez olacaktır. Belirli bir biçime ulaşmak için görülebilir frekans aralığına denk gelecek şekilde fotoğrafın yeniden 'kodlaması' gerekir.

Bu noktada, 'görüngüleri kasteden geleneksel imge'den 'kavramları kasteden teknik imge' ye ulaştıran diyalektik daha anlaşılır olacaktır: Önce, doğanın şeylerinin nesnelleşmemiş temsilleri olan görüngüler -zihinsel olarak- vardır, daha sonra bu görüngüleri temsil eden geleneksel imgeler gelir. Bu anlamda, geleneksel imgenin ereği görüngüdür. Fotoğraf ise, nesnelleşmiş bir görüngüdür: Geleneksel imgenin ereğinin gerçekleşimidir. Nesnelleşen bir görüngü, 'nesnel' olduğu için, temsili sistem içinde sadece bir görüngü olmaktan ötesidir. Fotoğraf, bir yanıyla nesnel bir imge, bir yanıyla görüngü olarak deneyimlenir. Görüngünün bir kez nesnelleşmesi, sonsuz bir döngünün kapısını aralar: Fotoğrafa bakmak, görüngü ve nesnel imge arasında hızlı bir gidip gelmedir. Fotoğraf, sürekli kendini aynalayan bilinç süreci için etkili bir uyarıcıdır. Fotoğraf, imgesel yaşantıyla kavramsal düşünce arasındaki farkı da bu döngüyle silikleştirir ve bunun ötesine sıçramak için bir basamaktır: Görüngüsel gerçekçiliği imgeye; nesneleşerek oluşturduğu dolayım, kavrama dairdir. Fotoğraf, görüngüyü kültürel bir nesne yapar, 'bakış'ı dolaşıma sokar, onu üretilebilir ve tüketilebilir bir şey yapar.

Fotoğraf, kendi kendinin göstereni (Barthes, 1996: 6) olarak düşünülmediği tüm durumlarda dünyanın şeylerinin temsili olan görüngünün ve görüngünün temsili olan geleneksel imgenin ötesine geçer. Başka bir şeye göndermesi, temsili sistem içindeki varlığının koşuludur. Gönderdiği şey, geleneksel imgelerin tek boyutlu, doğrusal açılımına olanak sağlayan, onların 'açıklamasını' yapan, geleneksel imgelerden sonra gelerek ikinci arabulucuyu oluşturan 'kavram'dır. Geleneksel imge, görüngüden doğarken; teknik imge, geleneksel imgeden doğan doğrusal düşünceden, yani kavramdan doğar: Sonuç olarak teknik imge, metne dayalı doğrusal düşünceyle işleyen bilimin ürünüdür (Flusser, 1991: 17). Özetle, dünyanın şeylerinden doğan tüm medya, görüngülerden geleneksel imgelere; geleneksel imgelerden kavramlara; kavramlardan teknik imgelere doğru bir genişlemedir. Bu 
genişleme, aynı zamanda düşüncenin genişlemesidir: Örneğin, renk veya hareket, fotoğrafa eklenen gerçeklikler değil; dünyadan soyutlanan şeylerin imgelere geri verilmesi; onların somutlanmasıdır. Flusser' in 'teknik imge' kavramlaştırması, bize bu bakış açısını sağlar. Bu da teknik imgeye, dünyayı kavrayışımızı -yazının icadıyla gerçekleşen kadar- köklü bir şekilde değiştirme potansiyelini veren şeydir.

Doğrusal düşüncenin yeri olan yazının çözülüşü, onun kurallarından yola çıkarak dünyayı anlamlandırdığımızı fark etmemizle başlar. Yazının kurallarını evrenin işleyişine yansıtmak, yazının bir arabulucu (medyum) olduğunu fark edememekten ileri gelir. Ancak, artık o da imgesel bilincin voodoo'ları gibi görünmektedir: Daha işlevsel bir biçimde de olsa, dünyayı kendi kurgusunda işlemek üzere tasarlar. Öyleyse, artık, ortada biçime olanak verecek boyut olmamalıdır. Geriye sadece boyutsuz parçacıklar kalır. Teknik imgeler, bu parçacıkların somutlamalarıdır. Dünyanın şeylerinin hesaplanmalarıla elde edilirler ve parçalanmış bilincimizi somutlarlar.

"Dalgalar damlalara, yargılar baytlara, davranışlar davranış birimlerine dönüştükçe bir boşluk meydana gelmektedir: Temel noktalar birbirinden ayıran ve böylece, noktaları ölçümünde imkansızlığa sebep olan boyutsuz bir boşluk. Böylesine ayrışııs ve soyut bir bilinçle, böyle boş ve soyut bir evrende yaşanamaz. Yaşamak için, evreni ve bilinci somutlaştırmaya çalışmak gerekmektedir. Parçacıkları, önemli (kavranabilir, akla uygun, somut) yapmak için birleştirmek gerekmektedir. On yedinci yüzyılda kalkülüsü icat edenler, bu aralıklarn doldurulması sorununu çözmüş, sonsuzluğu bütünleştirerek farklllklarn çözmüştür. Ama o zaman, sorun metodolojikti ve bugün; varoluşsal bir mesele, bir yaşam ve ölüm meselesi haline gelmiştir. Teknik imgeleri bu sorunun cevabı olarak görmekteyiz." (Flusser, 2011: 15-16)

Bu parçacıklı yapıda uzam ve hareket, matematiğin sayılarına ve geometrinin noktalarına indirgenmiştir. Boyutsuz noktalar ve ideal bütünlüklerin temsilleri olan sayılar, Flusser'in Cennet'ten kovuluş efsanesiyle temellendirdiği bölünmeden itibaren yanımızda taşıdığımız 'bütünlüğgün' en net sembolleridir: Satır aralarında gizlenen 'anlatılamaz' olana yaklaşan, üzerinde en az şüphe duyulacak bütünlük fikirlerinin en güçlü sembolleri. Noktalar, sayılar ve diğer tüm matematiksel ve geometrik soyutlamalar, dünyanın şeylerini ölçüp biçmiş, neredeyse tüm evreni Kartezyen bir ızgaranın içine hapsetmeye çalışmıştır. Teknik imgeleri oluşturan ise, nokta ve sayıların kendisidir. Buradaki fark budur: Dünyanın şeylerini hesaplamaya yarayan araçlar, kendi dünyalarını yaratmaktadır. Öyleyse, teknik imgeler, şeylerin tasviri değildir: Onlara ancak, görselleştirme denebilir. Ve görselleştirme süreci, tüm bu soyutlama sürecinin tersine doğru işler:

“Görselleştiricinin davranışı, bir parçacıktan asla elde edilemeyecek olan bir yüzeye doğru yönelirken, geleneksel imge üreticisinin nesnesi, nesnelerin dünyasından gerçek bir yüzeye doğru yönelir. İlk davranış, somutlamaya çalışır (aşırı soyutlamadan düşünülebilir olana); ikincisi soyutlar (somuttan çekilir). İlk davranış bir hesaplama ile başlar, ikincisi yekpare bir nesne ile başlar. Kısacası, burada, birbirine karışmış gibi göründükleri halde birbirlerinden tamamen farklı şekilde tasarlanan iki imge yüzeyi ile ilgilenmekteyiz (dermis ve epidermis gibi)." (Flusser, 2011: 21)

Flusser, Bazin'den aşina olduğumuz 'gerçekliğin izi olarak fotoğraf' düşüncesine bir karşı çıkış geliştirir. Bir evin fotoğrafı ve inşa edilmek üzere bilgisayarla oluşturulmuş bir uçak modelini karşılaştırır: 


\begin{abstract}
"Evin fotoğrafçısl, bilgisayar operatörünün yaptı̆̆ı gibi bir şeyi görselleştirir. Aslında olduğu gibi değil, olması gerektiği gibi bir ev görselleştirmektedir. Evi keşfetmekten çok icat etmiştir. Ve ev, görüntünün sebebi değil; göreceğimiz gibi, etkisidir. Bu nedenle fotoğrafçıdan bir ev modeli ürettiğini söyleyebiliriz. Öte yandan, bilgisayar operatörünün uçak tasviri yaptı̆̆ı da söylenebilir. Fotoğrafçı için olduğu gibi, neyin gösterileceğine dair bir imge ve kavram önceden vardır ve tasvir ettiği şey de budur. Teknik imgeler alanında tasviri ve modeli ayırt etme girişimindeki kayıp sebep, hangi biçimde olursa olsun onların yeniden üretim değil, üretim olmalarıdır. Aynı görselleştirme gücü hepsinde işlemektedir." (Flusser, 2011: 44)
\end{abstract}

Flusser, teknik imge çeşitleri üzerinde tek tek durmaz. Teknik imgeye genel bir tanım getirir. Teknik imgeler, dünyanın aynası değil; projeksiyonlardır ve bu sebeple anlamlarını dış dünyadan değil, içsel olandan alırlar: Dünyanın şeylerini göstermezler, dünyaya anlam veren onlardır (Flusser, 2011: 43-48). Henüz metinlerle enfekte olsalar da, tüm teknik imgeler, gelecekteki temsilden bağımsız 'görselleştirme gücü'nün habercileridir (Flusser, 2011: 37).

\title{
Flusser'in Soyutlama Modeli
}

Vilém Flusser'in beş basamaklı modeli, tüm kültür tarihinin somuttan soyuta; dört boyuttan boyutsuzluğa doğru bir ilerleme olduğu tezini savunur. Bu süreçte, araçlar ve medya biçimleri, düşünce biçimleriyle paralel bir dönüşümdedir. Düşünce biçimlerinin değişimi, elbette, araçların değişimine de dairdir. Ancak, bu değiş̧im, anlamlı, açık-seçik bilginin, yani 'mesaj' ın taşıyıcısı olan medyada belirginleşir.

Modelin beş basamağı şu şekildedir (Flusser, 2011: 6-7):

"Illk basamak: Hayvanlar ve "ilkel" insanlar, dört boyutlu bir uzay-zaman sürekliliği olan canlı bir dünyaya gömülüdür. Bu somut deneyimin seviyesidir.

İkinci basamak: Nesnel bir durumla karşı karşıya kalan bizden önceki insan türleri (yaklaşık iki milyon ila kırk bin yıl önce), kavranabilir nesneler içeren üç boyutlu bir durumun içindeydi. Bu, taş bıçaklar ve oyma figürler gibi nesnelerle karakterize edilen kavrama ve şekillendirme seviyesidir.

Üçüncü basamak: Homo sapiens sapiens, kendisi ve çevresi arasında konumlanan hayali, iki boyutlu bir arabuluculuk bölgesine girmiştir. Bu, mağara resimleri gibi geleneksel resimlerle karakterize edilen gözlem ve imgelem seviyesidir.

Dördüncü basamak: Yaklaşık dört bin yıl önce, doğrusal metinlerden oluşan başka bir arabuluculuk bölgesi, insanoğlunun görüşlerinin çoğunu borçlu olduğu bir bölge olan insanlar ve onların imgeleri arasında belirmiştir. Bu, anlama ve açıklama seviyesidir, tarihsel seviyedir. Homer ve İncil gibi doğrusal metinler bu seviyededir.

Beşinci basamak: Metinler kısa bir süre önce kendilerine erişilemez olduklarını göstermişlerdir.Onlar, dahafazlaresimselarabulucuyaizinvermemektedir:Belirsizleşmişlerdir. Metinler, toplanması gereken parçacıklar olarak çökmüştür. Bu, hesaplama (calculation) ve işlemleme (computation) seviyesi; teknik imgelerin seviyesidir."

Flusser, bu modelle kültürel tarihi şemalandırma amacında olmadığını; seviyeler arası geçiş aşamalarını vurgulamayı ve geleneksel imgelerin ve teknik imgelerin dünyaya dair somut deneyimden yabancılaşmanın tamamen farklı türleri olduklarını gösterme amacında olduğunu belirtir. Teknik imgeler, geleneksel imgelerle benzerlik gösterseler de, kültürel bir devrime sebep olacak ölçüde farklı bir şekilde 'kastederler'. Somut deneyimden teknik 
imgelerin evrenine doğru atılan adımlar, özetle şu şekilde gerçekleşmektedir (Flusser, 2011: 8-10):

Birinci Adım: İnsanlar, elleri sayesinde nesnel dünyayı biçimlendirerek onu "durdurur". Böylece, yaşam dünyası iki alana ayrılır: Sabit, anlaşılmış nesne alanı (nesne) ve alımlayanın alanı (özne).

İkinci Adım: Elin hareketlerini takip eden göz, elin kavrayamadığını; ilişkileri kavrar. Böylece, durumlar ve özne arasında iki boyutlu bir imge alanı üretilir: Geleneksel imgelerin alanı.

Üçüncü Adım: Dünyayı değiştirmenin yolu, dünyanın şeylerinin önünde duran imgeleri değiştirmekten geçer. Bu imgeler, değiştirilmek üzere kavranamamakta; ancak, hesaplanabilmektedir. Doğrusal metinler bu ihtiyaca yönelik olarak ortaya çıkmıştır. Onlar, imgesel boyuttan bir boyutu daha soyutlayarak metinlerin tek boyutlu kavramsal evrenini oluşturur.

Dördüncü Adım: Dünyaya dair yargıların dünyadan değil; doğrusal yazıya bağlı düşünce biçiminden kaynaklandığı anlaşılmıştır. Bu durumda dünya, yeniden birleştirilmesi gereken boyutsuz parçacıklar haline gelir. Teknik imgeler bu işlevi yerine getirmektedir.

Flusser'in akıl yürütmesinden yola çıkarak teknik imgelere bir tasnif geliştirilebilir: Teknik imgeler, geleneksel imgelerin aksine, somutlamalarsa, soyutlama sürecinin aksi yönüne doğru teknik imgeler üzerinden bir somutlama süreci tanımlanabilir. Bir evin fotoğrafının bir ev tasviri olduğuna dair sağduyumuz, görüngüsel gerçekliğimize olan inancımızdan kaynaklanır ve bu inanç, -her inanç gibi- aşama aşama yitirilmektedir. Böylece, somutlama süreci, teknik imgenin görüngüsel gerçekliği gösterme niyetine bağlı olarak, fotoğraftan sinematografik imgeye ve oradan da dijital imgeye doğru ilerleyen teknik imgenin tarihselliğiyle paralellik gösterecektir.

Elbette, bu yaklaşım, teknik imgelerin, -geleneksel imgelerin aksine- dünyanın değil; düşüncenin sınırları ölçüsünde yaratıcı potansiyele sahip olduğuna dair Flusserci yaklaşımın esas noktasının kaçırıldığı anlamına gelmemektedir: Teknik imgelerle gerçekleşen somutlama sürecine, soyutlama sürecinde olduğu gibi bir son belirleme niyeti taşımaz. Halihazırda dijital imgelerde bu sonsuz potansiyeli görmekteyiz. Bu yaklaşım, dünyaya karşı duruşumuzdaki 'terse dönüş' ün fenomenolojik açıdan eksik kaldığı yeri tamamlamayı amaçlamaktadır.

Teknik imgenin sonsuz imkanına rağmen, kültürel soyutlanma sürecinin bir başlangıcı vardır: Dört boyutlu uzay-zaman sürekliliği. Ve bir noktadan sonra teknik imge, 'ev tasviri' sandığımız 'ev modeli'ni kendinde gerçekleştirerek bizi, evin nesnelliğini aşmaya yönelttiği gibi, uzay-zamanı kendinde gerçekleştirerek, yani modelleyerek uzay-zamanı aşmaya yöneltecektir. Bu durum gerçekleştiğinde teknik imge, dünyanın imgesi olmayı tamamen bırakarak kendi imgesinde dünya'yı (Deleuze, 2014: 83) meydana getirebilir.

\section{Sinematografik Yanılsamadan Zaman-İmge'ye Flusserci Bir Yaklaşım}

Görüleceği üzere, Flusser'in kültür modelinde bir aşamadan diğerine geçiş, bir soyutlanmayla başlar ve bir somutlamayla ${ }^{2}$ sona erer. Somutlanan şey, yine bir somutlamayla

2 Burada, "nesneden gerçek bir yüzeye doğru olan soyutlama davranışı" ile "parçacıklardan asla elde edilemeyecek bir yüzeye doğru olan somutlama davranışı" ayrımı, imge üreticisinin amacına (somutlama) işaret etmek adına geçici olarak askıya alınmıştır. 
son bulacak yeni bir soyutlanmanın katalizörüdür. Özne, her soyutlanışında dünyanın bir boyutunu -deyim yerindeyse- yutar. İçselleşen boyut, artık, nesneye değil, özneye dairdir. Bu sebeple her somutlama, bir öncekinden bir boyut eksiktir. Ve tam olarak bu eksiklik, yeni bir soyutlanmayı mümkün kılar. Şimdi, modelin basamakları arasındaki geçişleri soyutlanan ilk boyut olan zaman üzerinden yeniden değerlendirebiliriz.

İnsan, ilkin, kendini uzay-zaman bütünlüğünden soyutlar. Zaman, özneye içsel bir şey haline gelir ve böylece özne, -örneğin rüzgarın ve suyun 'zamanla' yaptığı gibi- dünyanın üç boyutlu nesnelerini şekillendirme gücünü elde eder. İçsel zamana sahip olmanın asıl belirleyici yanı, şeyleri şekillendirme gücünü değil, şeyleri durdurma gücünü vermesidir: Durdurulan şeyler, somutlamalardır. İlk aşamada bu somutlamalar, elle kavranabilen kültürel nesnelerdir.

Gözle görülenin -elin kavrayamadığı şey olan- ilişkileri kavrayabilme kapasitesiyle birlikte gerçekleşen ise, üç boyutlu nesneler dünyasından iki boyutlu imgesel düzleme doğru bir soyutlanmadır. Bu noktada içselleşen şey, uzamın dünyanın şeylerini keskin bir biçimde birbirinden ayıran üçüncü boyutu, yani derinliğidir. İçselleşen derinlik, düşünceyi, şeyler arasındaki ilişkilere yoğunlaştıracak imgesel düzlemi meydana getirir: Derinlik, şeyler arası ilişkilerin taşıyıcısı olan yüzeye dönüşür. Bu imgesel bilincin somutlamaları, iki boyutlu imgelerdir. İki boyutlu imge, zamanın gücüyle durdurulmuş, derinliğin yüzeye doğru sıkıştırılmasıyla da, nesneler arası ilişkiselliğin bütünsel temsillerine olanak sağlamıştır.

İki boyutlu imgenin bütünselliği daireseldir. Bu sebeple, elde edilen zamanın onda oynadığ1 rol, hâlâ onu durdurmaktan ötesi değildir. İmgeye bakan göz, dünyanın şeylerine bakarken olduğu kadar özgürdür. İmgenin her öğesi, göz gezdirmenin rastgeleliği ölçüsünde diğer bir öğeyi önceleyebilir veya sonralayabilir. İmgelerle birlikte fark edilirliği artan şey, nesneler arası ilişkilerin determinist karakteridir. Özne, bu neden-sonuçluluğu sağlamak üzere bir boyutu daha içselleştirir ve geriye tek boyut kalır: Doğrusallık. Bu sefer düşünce, öğeler arasındaki ilişkileri somutlamaya yönelir. Yazının öğeleri, yalnızca nesnelerin değil, nesneler arası ilişkilerin sembolleridir: Nesneler arasındaki gizli okların somutlamalarıdır: Oklar tek yönü gösterir. Bu aşamada, içselleşen zaman sadece durdurmaz; gözlerin serbest hareketini, önce ve sonranın doğrusallığında hareket etmek üzere sınırlar. Doğrusal yazı, içsel zamanın gücüyle durdurulmuş bir şey olmakla birlikte, nesne-zaman ilişkisine göre, yani zamana dair ampirik bir bilgi (neden-sonuç) doğrultusunda gözün hareketini sınırlandıran şeydir. Yazının da kendinden önceki somutlamalar gibi durdurulmuş olduğu doğrudur, ancak bu sefer göz, zamanın hareketini ödünç almıştır.

Öyleyse, bu aşamaların tersine doğru gerçekleşecek bir somutlama; tek boyutun doğrusallığına, iki boyutun daireselliğe ve üç boyutun uzamına aynı anda sahip olmalıdır. $\mathrm{Bu}$ durum, sinematografik imgede gerçekleşir. Sinematografik imge, uzay-zamanın parçalara ayrılıp yeniden birleştirilmesidir: Dört boyutun temsilidir.

Sinematografik imgenin kareleri, iki boyutlu daireselliği; karelerin art ardalığı, tek boyutlu doğrusallığı; bu doğrusallık ise, -iki boyutlu yüzeyde- üç boyutlu derinliği sağlar. Dairesellikle sağlanan doğrusallığı (imgelerinin art ardalığı), doğrusallıkla sağlanan derinliğiyle (art ardalıkla sağlanan hareket) o, zamanın içeriden oluşmasını sağlayan çarpık bir evrendir: Zamana bağlı üç boyut, üç boyuta bağlı bir zaman, yani, mekana bağlı bir zaman oluşturur. Bu, Bergson'un sinematografik yanılsama dediği şeyden başkası değildir. 
Sinematografik yanılsama, Henri Borgson'un, özne-nesne düalizmini durağan bir düzlemde tasarlayan felsefelere karşı geliştirdiği süre felsefesini desteklemek üzere kullandığ1 bir metafordur. Sinematografik yanılsama, en kısa biçimiyle, sinematografik işleyişin dünyanın şeylerinin işleyişine yorulmasıyla gerçekleşen bir yanılsamadır ve Bergson'a göre felsefe ve bilim bu yanılsamanın etrafında şekillenir.

Bergson, sinematografik yanılsamaya tartışmasına varlık-hiçlik problemine değinerek başlar. Böylece, Flusser'in de üzerinde durduğu gibi, karşıtlıklara başvurmadan dünyayı tasarlayamadığımız belli bir düşünce biçimine dikkat çeker. Varlık ve hiçlik, düşüncenin dünyaya dair en uç tasarımlarıdır: Karşıtlığın iki uç tarafıdır. Varlık ve hiçlik, düşüncenin dolaşımını mümkün kılan iki dünya imgesidir. Bu dolaşım kesintilidir, çünkü varlık ve hiçlik, birbirinden ayrı iki sonsuzluk imgesi gibi tasarlanmaktadır. Hiçlikten varlığa doğru bir oluşun tasavvuru, bir biçimden başka bir biçime doğru oluşun tasavvurunu mümkün kılan temel bölünmeyi oluşturur. Sinematografik yanılsama işte tam bu noktadadır: Kesintisiz bir oluşun içinden birbirini izleyen durağan imgeler çekilip çıkarılır ve birbiri ardına dizilerek bir çeşit hareket sağlanır. Dünyanın verili şeyleri olarak kavranan bu imgelerin arasındaki ilişkiler, aynı zamanda dünyanın şeylerinin ilişkileri olarak kavranır. Burada, kesintisiz bir oluş karşısında açıkça bir yanılsama olan bilincin sinematografik işleyişinin, dünyanın kanunları olarak kavranması söz konusudur (Bergson, 1947: 349-400).

Böylece dilin, matematiğin; nesneleri veya nesneler arası ilişkileri temsil eden tüm sembolik yapıların dünyanın kanunları olarak düşünülmeleri kaçınılmazdır. Onlar, dünyada görmek istediğimiz şeylerden başkası değildir. Flusser'in dünyanın kuralları olarak varsaydığımız şeylerin dünyadan değil, doğrusal yazıdan kaynaklandığını fark ettiğimizi söylediğinde bahsettiği şey de budur. Ancak, gözü bir akışa yönlendiren yazının aksine sinematografik imge, kendi akışına sahiptir. Bununla beraber göz, bağımsız döngüsel hareketini bu sefer, akmakta olan imgelerin üzerinde tekrar elde eder.

Nesnelleşen bir görüngü olarak fotoğraf, oluştan çekilip çıkarılan durağan imgeleri temsil sistemine dahil etmişken; sinematografik imge, 'bir oluşun temsilini' temsil sistemine dahil etmiştir: İmgeler, ilişkisellikleriyle birlikte gösterilmektedir. Bu sebeple, sinematografik imge, bir farkındalığın ötesine; yeni bir kavrayış biçimine sıçramayı mümkün kılan bir aracı olma potansiyeline sahiptir. Deleuze, sinematografik imgeyi, imgeye eklenmiş bir hareket olarak değil, dolaysız bir hareket-imge olarak kavrarken (Deleuze, 2014: 13) bu açıdan bakmaktadır. Sinematografik imge, mekanı ve zamanı yeniden düzenleme imkanını sağlayan şeydir: Mekan ve zaman, artık, Flusserci anlamda 'kavranabilir' şeylerdir.

Flusser'in modelinde her somutlama, düşüncede bir sıçrama meydana getirecek yeni bir soyutlanmaya olanak sağlıyordu. Zaman-mekanın yeniden düzenlenebilmesi imkanı açısından hareket-imge, bu sıçrama için mümkün zemini hazırlamıştır. Zaman-imge ise, Flusser'in temsildeki terse dönüş iddiasının fenomenolojik anlamda gerçekleştiği noktadır. Zaman-imge, dışarıdaki bir şeyi göstermeyen kendinde imgedir. $\mathrm{O}$, dünyanın şeylerine dönmek üzere kendine dönen düşüncenin aksine; özne-nesne bölünmüşlüğünü geride bırakarak, yeniden düşüncenin koşullarına dönmek üzere kendine dönen düşüncedir. Üç boyuttan doğan iki boyutlu imgesel düzlem, iki boyuttan doğan tek boyutlu doğrusallık gibi; zaman-imge, sinematografik imgenin nesnelliğine dair olmayan, ama sinematografik imge vasıtasıyla erişilen yeni bir soyutlanma seviyesine işaret eder: "Saf bir optik ve sessel durum hareketin içinde genişlemez, daha çok, bir hareket tarafından uyarılır." (Deleuze, 1997: 18) 
Bilindiği gibi, harekete bağlı antik zaman anlayışı, zamana bağlı hareket anlayışına evrilmiştir. Kant, zamanı a priori olarak niteleyerek, Descartes' 1 n düşünen öznesini de yerinden eder: ‘Düşünüyorum'dan 'o halde varım'a ulaşılabilmekte ancak, 'ben düşünen bir şeyim'e ulaşılamamaktadır. 'Düşünüyorum'dan 'o halde varım'a geçişte belirleme (düşünüyorum) bir belirlenmemişi (varım) ima eder. Burada bir süreksizlik yoktur ancak, 'düşünüyorum' tarafından belirlenen 'varım'ın hangi biçim altında gerçekleştiği belli değildir. Kant için bu biçim, zaman biçimidir (Deleuze, 2000: 60-62). Bergson ise, Kant'ın öznel zamanının karşısına dışsal, kronolojik olmayan zamanı, bölünemez olan süre'yi koyar. Bilinçte birbirini izleyen, yani art arda gelen imgeler vardır. Uzamda ise bir art ardalık yoktur, eşzamanlı dışsallıklar vardır. Zihinsel art ardalığın, dünyanın şeylerine yorulmasıyla sinematografik yanılsama gerçekleşir (Sütçü, 2015: 132-133). Ancak, Deleuze'ün zaman-imge kavramlaştırması, fotoğrafların art ardalığıyla elde edilen, kısacası sinematografik algıyı bir aygitla yeniden oluşturan hareket-imgenin bölünemez bütünlük olan süre'yi 'kastedebilme' potansiyelini vurgular: Bu potansiyel, art ardalığın öznede değil, öznenin önünde gerçekleşmesiyle; yani, hareket-imge' nin temsil sistemine girmesiyle açı̆̆a çıkar.

Bir uzay-zaman bütünlügünün, -Bergsoncu anlamda sürenin- doğrudan temsili olması sebebiyle herhangi bir nesnellikten soyutlanma olarak nitelenemeyecek olan bu soyutlanma durumu, öznenin kendinden bir şeyleri soyutlamasını mümkün kılar. Kendinden soyutlanan öznelliğin, bu sefer kavramak üzere üzerine eğilebileceği şey, yine öznelliğin kendi öğeleri olacaktır. Zaman-imge, dil ağının öğeleri arasındaki 'anlatılamayan'ı kavramanın yoludur: Kavramın kavrayamadığını kavrar. Bu, kavramlara yönelen dilsel düşünümün sınırlarını aşarak kavramın koşullarına (zaman'a) yönelen imgelerle kurulan 'imgesel düşünüm'dür: Düşünce, kendine doğru (geriye) yönelmez; her yöne doğru açılır. Zaman-imge, hareketin ötesine, zamanın doğrudan kendisine işaret eder; ve böylece, fizikte mikro ölçeklere inildiğinde determinist makro evrenin yapısal temeli olan indeterminist parçacık evreniyle karşılaşıldığı gibi, yüzeydeki rasyonel öznelliğin rasyonel olmayan yapısına nüfus edebilecektir.

\begin{abstract}
"Modern bilimsel devrim, hareketi ayrıcalklı anlarla değil, herhangi bir anla ilişkilendirmekten ibarettir. Her ne kadar hareket hala yeniden oluşturuluyorsa da artık aşknn biçimsel öğelerden (pozlar) değil içkin maddesel öğelerden (kesitler) oluşturulmaktadır. Hareketin kavranabilir bir sentezini yapmak yerine, ondan duyusal bir analiz türetilmekteydi. Bu şekilde, bir yörünge ile bu yörüngenin çevresinde dolaşmak için gereken zaman arasındaki ilişki belirlenerek modern astronomi (Kepler); düşen bir cismin katettiği mekan ile düşüş zamanının birbiriyle bağlantılandırılmasıyla modern fizik (Galileo); düzlemdeki bir eğrinin denkleminin, yani bir noktanın hareketli bir doğru üzerindeki ilerleyişinin herhangi bir anındaki konumunun formüle edilmesiyle modern geometri (Descartes); ve son olarak, sonsuzca birbirine yaklaştırlabilecek kesitleri ele alma düşüncesinin bulunmasılyla sonsuz küçükler hesabı (Newton ve Leibniz) kurulmuştur. Her alanda, herhangi anlarn mekanik olarak birbirlerini takip etmesi pozların diyalektik düzeninin yerine geçmiştir." (Deleuze, 2014: 15)
\end{abstract}

Bu noktada, Bergson'un “Modern bilimin zamanı bağımsız bir değişken olarak alma isteği" ile tanımlanabileceği tespitini (Bergson, 1947: 430) kanıtlamak üzere örneklediği modern bilim yöntemlerini özetleyen Deleuze'ün sıralamasına zamanın bağımsız değişken olma özelliğini yitirmesiyle birlikte hesaplanabilir kesinliklerden olasılıklara doğru bir paradigma kaymasına uğrayan fizik doğrultusunda ekleme yapabiliriz. Bağımsız değişken olarak zaman, Einstein'ın ışık hızının referans sistemine göre göreceli olmadığına dair kanıtlar öne sürmesiyle birlikte geçerliliğini yitirmeye başlar: Hareket etmek için herhangi bir ortama 
gerek duymayan ışığın hızı, evrensel bir sabit oluşturmakta ve böylece, klasik fiziğin hareketi belirleyen mutlak zaman anlayışı çözülmektedir. Özel görelilik kuramınca mekan, zaman ve hareket; bakış açılarınca görecelidir. Özel göreliliği kapsayan genel ilke Genel görelilik ise tüm uzayı dört boyutlu bir doku olarak tasarlayarak zaman-mekan özdeşliğine işaret eder: Artık, harekete bağlı bir zamandan ya da zamana bağlı hareketten bahsetmek mümkün değildir (Greene, 2010: 56-57). Heisenberg'in bir parçacığın momentumunun ve konumunun aynı anda tam doğrulukta ölçülemeyeceğini belirten belirsizlik ilkesi'nin (Greene, 2010: 118) kabul görmesiyle birlikte, fizik, hesaplanabilir kesinlikler evreninden uzaklaşarak bir olasılıklar evreni tasarlamaya doğru yönelir. Hesaplanabilir kesinliklerden olasılıklara doğru yönelim, ilk bakışta mümkün bir gerçeklikten uzaklaşma gibi görülse de; esasında 'hesaplanabilir' olanın 'olasılığa' dönüşümü, daha önce 'mümkün olmayan'ın bir olasılık değeri kazanmasını sağlar. Diğer yandan, 'olasılık', indeterminist parçacık yapısını rasyonalize etmenin yoludur: Fiziğin, maddeden determinist bir örüntü çıkarma çabasının devamıdır. Sonuç olarak, olasılık da nicel bir değerdir ve değerini indeterminist evrenin bir olasılık olarak kalmaya zorladığı nedensel evrenin kanunlarından (Flusserci bir tanımla: Düşünceyi sınırlayan şüpheden) alır.

\begin{abstract}
"Teknik imgelerin üretimi, bir olasılıklar alanında gerçekleşir: Parçacıklar, kazara ortaya çıan şeylerden başka bir şey değildir. Başka bir deyişle 'olasıllk', evrenin ve bilincin beliren şeyleridir. (...) Olasılığın iki ufku, 'kaçınılmaz' ve 'imkansız'dır: Kaçınılmaz olanın yönünde olasılık, mümkün hale gelir; imkansiz olanin yönünde olasillk, beklenmedik hale gelir. Böylece, beliren evrenin ve bilincin temelini olasılı̆̆ın hesaplanması oluşturur. Şu andan itibaren 'doğru' ve 'yanlış' gibi kavramlar sadece ulaşılamaz ufuklara işaret etmekte, sadece epistemoloji alanında değil; aynı zamanda ontoloji, etik ve estetik alanında da bir devrim yaşanmaktadır." (Flusser, 2011: 16-17)
\end{abstract}

\title{
Sonuç
}

Flusser' in "teknik imge" si, -bu makalede belirli bir yönüne odaklanılsa da- bir telematik toplum ütopyasının anahtar kavramıdır. Telematik toplum; post modern, sanayi sonrası, simülasyon çağı, enformasyon çağı gibi farklı isimlerle anılan; tarihi bile anlamsızlaştıran bir paradigma değişimi olduğu için bir "tarih aralığı" bir "dönem" demenin de zor olduğu; tanımlama ölçütleri de yerinden olduğu için "tanımlaması zor" olan; işlevini yitirmiş ölçütlerle bir örüntü yakalayarak "gerçek yüzü" açığa çıkarılmaya çalışılan bir 'kriz’e çözüm önerisidir.

'Kriz' kelimesi, “yargılamak, hüküm vermek” (kritik) anlamına geldiği gibi, “hastalığın dönüm noktası" anlamına da gelen Yunanca krísis kelimesinden türemiştir. ${ }^{3}$ Artık, hastalığın dönüm noktasına hüküm veren bir doktor (otorite) kalmamıştır. Ya da durum, mental bir rahatsızlığa yakalandığını düşünen psikiyatristin kendini tedavi etme çabasına benzemektedir. Krizin izi, hangi yönden sürülürse sürülsün o kadar derinlere inilmektedir ki, bunun güncel bir kriz olup olmadığından bile şüphe edilmektedir. Yeni bir engelle karşılaşılmamıştır: Şimdiye kadar kendi eksenimizde döndügüumüz fark edilmiştir. Tüm insanlık çabası bir ouroboros $^{4}$ halini almış; ve böylece, her şeyle birlikte tarihin üzerine kurulduğu zaman da anlamsızlaşmıştır. Aslında bu, basitçe, geçmişe bakarak çağları adlandırır gibi, içinde bulunulan döneme ve dolayısıyla içinde bulunulan ruh haline isim verme çabası yüzünden karşılaşılan bir kısa devredir. Daha önce bu kadar kapsamlı bir adlandırma ve adların altını kavramlarla doldurma çabasına muhtemelen gerek duyulmamıştır: Politik, ontolojik, ahlaki, epistemolojik, estetik... değerler Tanrı'nın düzeninden saçılan, Tanrı'nın düzenine ulaştıracak 3 www.etimolojiturkce.com, "kriz" maddesi.

4 Kendi kuyruğunu isıran yılan. 
olan ipuçları olagelmiş; toplumsal ve bireysel motivasyonları sağlamıştır. Şimdi ise, üzerindeki uzlaşıların gittikçe çözülüyor gibi göründügü bir "gerçeklik" vardır.

Değişen medya biçim ve pratiğinin bu süreçte oynadığı rolü Flusser'le birlikte en erken kavrayan birkaç düşünürden biri olan Baudrillard' da gerçekliğe yaklaşımın en uç biçimlerinden biri görülür. Baudrillard, eleştirel gücünü, "gerçek" kavramına “Tanrı" kavramından da eski bir mit olma anlamını yüklemesinden alır. Gerçeğin olmadığına ikna olmak, Tanrı tasvirlerinden vazgeçmekten daha zordur. Çünkü "gerçek", varlığı herkesçe kabul edilen bireysel mitolojidir; inanılan şeydir. Baudrillard, gerçeğin olmadığını söylediğinde, inandığımız şeylerin aslında olmadığını söyleyerek ouruboros'un sonsuz döngüsüne dokunmaz: Görünen tüm şeyler, orijinali olmayan bir simülasyon; "kendi kendini aynı yörünge çevresinde dolanan modeller aracılığıyla yineleyen" (Baudrilard, 2014: 15) kapalı bir devre halini alır.

Flusser, bu sonsuz döngüye dair farkındalığı fırsata çevirir: Durumu, "tarih sonrası" olarak adlandırır. İlk bakışta "tarih sonrası", "post modern" gibi bir adlandırmanın aksine, paradoksal gözükmektedir. Paradoksu (ouroboros'u) ortadan kaldıracak olan şey de, bu adlandırmanın bir tarih aralığını değil; tarihselliği anlamsızlaştıracak bir bilinç biçimini ifade ettiğini görebilmektir (Kaldı ki, kanıksanmış bir "tarih öncesi” zaten vardır). 'Tarih sonrası'nı tahayyül edebilmek, ancak tarihle birlikte var olabilen bir 'gerçek'le ilgilenmeyen zihinsel bir durumla mümkündür. Flusser'in sibernetik açılımında bu yeni bilinç, Hegel'in özbilinçten yoksun nesnel tinine karşı özbilinçli nesnel tin gibidir. Telematik toplum, bireylerin yapabileceğinin ötesini tahayyül edebilen ve aynı zamanda "insanlığını" kaybetmemiş küresel bir beyindir (Flusser, 2011: 68). Flusser' in önerisi, şimdiye kadar biyolojik veya tarihsel rastgelelikte biçimlenmiş olan bilincin bu sefer "bilinçli bir şekilde" değiştirilmesidir. Teknik imgeler, bu değişimin enstrümanlarıdır. Kısacası, Flusser'in çözüm önerisinin pratik bir karşılığ vardır. Teknik imgeyi bu açlım için mümkün zemin yapan, onun, temsil sisteminin geçerliliğini yitirme tehlikesine; insan ile dünya arasında açılan uçurumda kaybolma tehlikesine karşı mümkün bir köprü olmasıdır. Ve bu köprünün inşası için elimizdeki malzemeyi tanımamız gerekmektedir.

Flusser'in önerdiği bu yolda ilerleyerek sinematografik imgeyi irdeleyen bu çalışmada özetle, şu sonuca ulaşılmıştır:

Sinemanın sembolik anlatıdan saf optik bir duruma (zaman-imgeye) geçişi, onun kendi içsel diyalektiğini oluşturur. Sinematografik imge, 'gösterilen şey'den bağımsız olarak zamanı kastetme potansiyeline halihazırda sahiptir. Sinematografik imgeyi, fotoğrafik imgeden farklı kılan nokta, onun dört boyutun temsili olması ve böylece, dünyaya dair somut deneyimin (uzay-zaman bütünlüğünün) somutlaması olmasıdır. Bir 'temsilde ters yüz oluş' tan bahsedecek olursak, sinematografik imge, bu ters yüz oluşun fenomenolojik kırılma noktasında bulunur: Fotoğraf, durumları; durdurulmuş görüngüleri somutlarken; sinematografik imge, oluşu somutlar. Sinematografik imge, bilinci, Bergson'un ne nesnel ne de temsili olarak tanımladığ1 varoluş biçimine yaklaştıran bir arabulucudur. Sinematografik imge, dört boyutlu uzay zaman bütünlüğ̈ünden, en yüksek soyutlukların temsilleri olan sayılarla, hesaplamalarla kurulan evrenlere doğru; boyutsuz bir düşünce alanına yükselişin nirengi noktasında bulunur. İnsan, dünyaya karşı, zamanın vektörel tasviri gibi; üç boyutu aynı anda dik kesen doğru parçası gibi 'doğrulmuştur'. Sinematografik imgeyle birlikte temsil sistemine dahil olan 'zaman'ın bizi soyutladığı nokta, zaman ötesidir. 
Bunlara ek olarak, Bergson'un sinematografik yanılsama problemine varlık ve hiçlik tartışmasından geçerek başlamasının nedeni bugün daha net görülebilir. Bilim ve teknoloji, temel bölünmüşlüğü; varlık ve hiçliğin sembollerini (1 ve 0 ) karmaşık simülatif somutlamalar üretebilecek ölçüde işleyebilen aygıtları mümkün kılmıştır. Gittikçe karmaşıklaşan aygıta karşın; kod, iki temel öğenin kombinasyonlarına indirgenmiştir. Dijital görselleştirme, matematiksel ifadeler yoluyla nitel ifadeleri mümkün kılmaktadır. Yeni tartışma, dünyaya karşı duruşumuzda etkili bir irrasyonel sapmaya sebep olma potansiyeline sahip olan dijital imgeler üzerinden başlatılmalıdır.

\section{Kaynakça}

Baker, Ulus, (2014). Kanaatlerden İmajlara Duygular Sosyolojine Doğru (Çeviren Harun Kemal Abuşoğlu), İstanbul: Birikim Yayınları.

Barthes, Roland, (1996). Camera Lucida Fotoğraf Üzerine Düşünceler (Çeviren Reha Akçakaya), İstanbul: Altıkırkbeş Yayın. Bakanlığ1

Bergson, Henri, (1947). Yaratıcı Tekâmül (Çeviren M. Şekip Tunç), Ankara: Milli Eğitim

Bergson, Henri, (2015). Madde ve Bellek (Çeviren Işık Ergüden), Ankara: Dost Kitabevi

Debord, Guy (1996). Gösteri Toplumu ve Yorumlar (Çeviren Ayşen Ekmekçi ve Okşan Taşkent), İstanbul: Ayrıntı Yayınları.

Deleuze, Gilles, (2000). Kant Üzerine Dört Ders. Öteki Yayınevi: Ankara.

Deleuze, Gilles, (1997). Cinema 2 The Time Image, Minneapolis: University of Minnesota Press

Deleuze, Gilles, (2014). Sinema I Hareket İmge (Çeviren Soner Özdemir), İstanbul: Norgunk Yayıncilık.

Fischer, Ernst, (1990). Sanatın Gerekliliği (Çeviren Cevat Çapan), Ankara: V Yayınları.

Flusser, Vilém, (1986). The Photograph as Post-Industrial Object: An Essay on the Ontological Standing of Photographs, Leonardo, Say1: 19, s. 329-332.

Flusser, Vilém, (1988). On writing, complexity and the technical revolutions. Interview in Onasbrück, European Media Art Festival, Erişim 5 Kasım 2018. https://www.youtube. com/watch?v=lyfOcAAcoH8

Flusser, Vilém, (1991). Bir Fotoğraf Felsefesine Doğru (Çeviren İhsan Derman), İstanbul: Ağaç Yayınları.

Flusser, Vilém, (2005). Thought and Reflection, Flusser Studies, Sayı: 1, s.7-12.

Flusser, Vilém, (2011). Into the Universe of Technical Images, Minneapolis London: University of Minnesota Press.

Greene, Brian, (2010). Evrenin Dokusu Uzay, Zaman ve Gerçekliğin Dokusu (Çeviren Murat Alev), Tübitak Yayınları: Ankara.

Hanke, Michael, (2004). The Communication and Media Theory of Vilém Flusser, Pioneer of Brazilian Media Studies, Porto Alegre: International Association for Media and 
Communication Research (IAMCR).

Jameson, Fredrich (1998). Cultural Turn: Selected Writings on the Postmodern 19831998. New York: Verso.

Stevenson, Nick, (2008). Medya Kültürleri Sosyal Teori ve Kitle İletişimi (Çevirenler Göze Orhon ve Barış Engin Aksoy), Ankara: Ütopya Yayınevi

Sütçü, Özcan Yılmaz, (2015). Gilles Deleuze'de İmge Hareketi Olarak Sinemanın Felsefesi, Bursa: Sentez Yayıncilık. 